\section{Paul Ives}

is managing director of Apollo

Business Research, a UK

independent commercial

property researchers. $A B R$

carry out outsourced property

research for nearly a dozen

major UK property market

clients in both the UK and

Europe.

Keywords

retail development, central London, demand, supply, innovative retailing, large units, vacancy rates
Paul Ives

Apollo Business Research Ltd

33 Tandridge Gardens

Sanderstead

Surrey CR2 $9 \mathrm{HW}$, UK

Tel: +44 (0) 2086512686

E-mail: paulives@blueyonder.co.uk

\section{Retail property development trends in the central London market}

\author{
Paul Ives \\ Received (in revised form): 21 February 2003
}

\begin{abstract}
This paper examines the trends in the retail property market in central London (City, Midtown, West End, Paddington, Southbank and Docklands) for 2003-2004 in light of the slowing economy, competition from suburban and out-of-town centres, congestion charging and lower tourism numbers. It looks at the plans of retail property developers and retailers and the effect on different submarkets of central London of the shifting balance of supply and demand.
\end{abstract}

\section{INTRODUCTION}

Many forecasters believed that there would be a deterioration in consumer confidence after September 11th. However, the effect up to early 2003 has been almost the exact opposite in the UK as retail spending hit new highs; the first sign of a tentative slowdown came at Christmas 2002, and even then last-minute spending almost replaced sluggish spending in early December.

Consumer spending levels are continuing to forge ahead, with a growth rate of over 5 per cent a year. Analysts are emphasising the impact of low interest rates, rising house prices and the low levels of unemployment, although the buoyancy of consumer spending still puzzles economists. Nonetheless, retail spending growth weakened in the last quarter of 2002 and it is widely expected that consumer spending growth will slow overall in 2003. How will this affect London retailers?

Retailer demand for new accommodation in central London slowed in 2002, as fears of declining GDP growth and increased retailer competition, especially in the fashion mid-price market, adversely affected retailers such as Marks \& Spencer and Arcadia (Debenhams). However, trading remains relatively buoyant, and retailers that had a good Christmas include Carphone Warehouse, with trading up 14 per cent, Perfume Shop, up 13 per cent, Jessops, up 8 per cent, New Look, up 8 per cent and Hamleys, up 6 per cent. Poor performers included Austin Reed, JD Sport, Dixons and First Sport. The retailers with growing revenues are likely to be looking for more units in 2003, but overall the mood remains one of caution. 
Low rental growth

\section{New schemes}

Some retailers, such as Next, Uniqlo and Spanish retailer Zara, continued their aggressive expansion plans across the UK and Europe. The UK is enjoying an increase in the number of foreign retailers on the high streets. In fact, the UK was the most popular destination for international retailers expanding in Europe in 2001 and 2002, helping retail vacancy rates continue on a downward trend in the majority of key UK cities.

\section{CONTEXT}

Despite the fact that consumer spending is growing at nearly 5 per cent a year, national retail rental growth is only hovering around 1 per cent per annum, which, taking into account inflation, is in real terms negative growth. Growth is strongest in the non-food sector, with textile, clothing and footwear stores recording sales growth of over 10 per cent per year.

Low rental growth is being driven by subdued retail demand in many areas. Nevertheless, retail yields remain relatively healthy, suggesting investors feel that capital and rental growth is sufficient compared to interest rates as long as they hold the right stock.

\section{THE LONDON EFFECT}

London, though, is bucking the trends - last year central London as a whole saw the highest average regional rental growth of anywhere in the UK at around 3 per cent as the increased pedestrian flows fed into a relatively finite number of shop units and new schemes attracted more shopping visits. Central London shopper numbers are estimated to be up 5 per cent on a year ago. Increased competition from suburban centres seems to have made little impact on central London shopper numbers.

In addition, population forecasts from the Office for National Statistics suggest that London's population will rise by half a million in the next 20 years (Figure 1).

Figure 1: London population growth

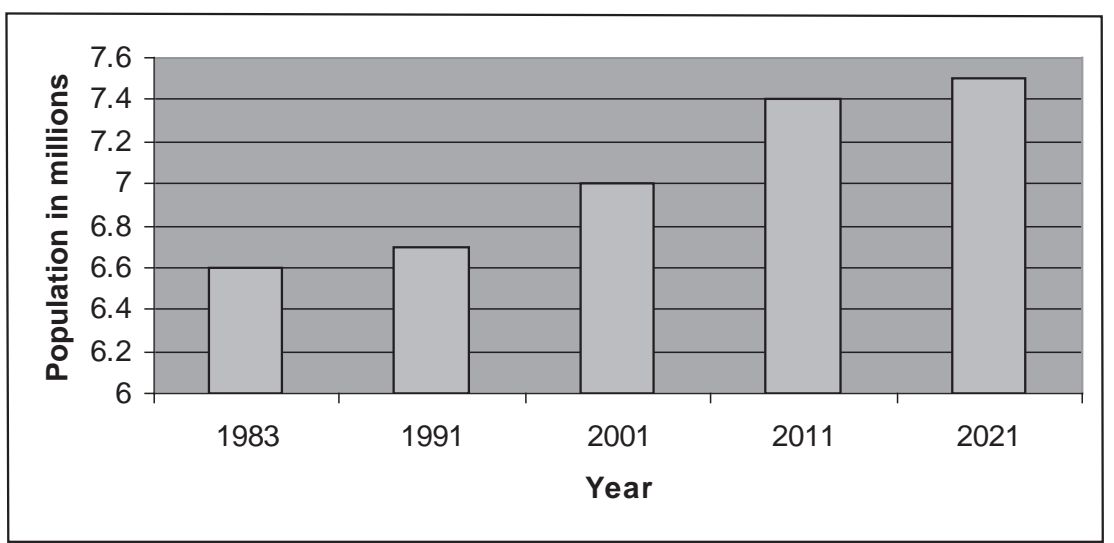


400 retail developments

\section{Paternoster Square}

Figures from Emap Glenigan/Freeman ${ }^{1}$ reveal that there are currently nearly 400 retail developments or schemes in central London's retail pipeline, each with a sizable retail element of $£ 1 \mathrm{~m}$ plus. These comprise 200 schemes at the early stage (planning application); 100 schemes with planning consent; and over 100 schemes which are under way or due to start in the next six months. Schemes range from small-scale redevelopments, such as the Plaza Cinema mixed-use scheme on Lower Regent Street, SW1, with around 20,000 square feet $\left(1,900 \mathrm{~m}^{2}\right)$ of new retail space, or a new office block in Broad Street Place in EC2, with just one large ground floor retail unit, to some of the large mixed-use schemes listed in Table 1.

Large retail schemes at an early stage include an enlargement of the Surrey Quays shopping centre in Docklands; Railtrack schemes at Victoria, London Bridge and Paddington stations; mixed-use redevelopment of the Astoria building on Charing Cross Road; Argent’s $£ 200 m$ Kings Cross Central scheme; Selfridges redevelopment on Oxford Street; and schemes for St Giles Circus in WC2, the Shell Building on the south bank and the Heron Tower scheme in the City.

Large schemes with planning consent include Chelsfield's $1.3 \mathrm{~m}$ square feet $\left(120,000 \mathrm{~m}^{2}\right)$ White City Centre, W12; the final phase of Knightsbridge Green in SW1; numerous office-topped City schemes; the refurbishment of the $1 \mathrm{~m}$ square feet $\left(92,900 \mathrm{~m}^{2}\right)$ Brunswick Centre in Bloomsbury, WC1, which is due to start in mid-2003; Bankside by the Tate Gallery in SE1; and up to 200,000 square feet $\left(18,000 \mathrm{~m}^{2}\right)$ at Battersea Power Station, just south of Victoria.

Large central London retail schemes currently under way include the new store for the House of Fraser at London \& Regional's 68 King William Street, EC2; new stores for Allders and JJB Sports on Oxford Street; the large mixed-use Lion Plaza scheme on Threadneedle Street in the City, which has already attracted Mappin \& Webb, Dixons, Starbucks, Gant, French Connection, Austin Reed and Diesel; the retail element of Paternoster Square, EC4, which is under construction; and the retail element of Chelsfield's Paddington Waterside which is under construction in W2. Meanwhile demolition has begun at the Land Securities' 550,000 square feet $\left(51,000 \mathrm{~m}^{2}\right)$ part-retail Stag Place redevelopment, fronting Victoria Street in SW1.

Table I: Large London mixed-use pipeline schemes with retail elements

\begin{tabular}{lll}
\hline Name & Total size & Stage \\
\hline Kings Cross, N1 & $6 \mathrm{~m} \mathrm{sq} \mathrm{ft}\left(557,600 \mathrm{~m}^{2}\right)$ & Early planning \\
Marsham Street, SW1 & $1 \mathrm{~m} \mathrm{sq} \mathrm{ft}\left(92,900 \mathrm{~m}^{2}\right)$ & Demolition \\
Brunswick Centre, WC1 & $1 \mathrm{~m} \mathrm{sq} \mathrm{ft}\left(92,900 \mathrm{~m}^{2}\right)$ & Starts mid-2003 \\
BBC, W1 & $800,000 \mathrm{sq} \mathrm{ft}\left(74,300 \mathrm{~m}^{2}\right)$ & Site preparation \\
Spitalfields, E1 & $700,000 \mathrm{sq} \mathrm{ft}\left(65,000 \mathrm{~m}^{2}\right)$ & Starts mid-2003 \\
Aldgate Union, E1 & $500,000 \mathrm{sq} \mathrm{ft}\left(46,500 \mathrm{~m}^{2}\right)$ & Planning consent \\
New Fetter Lane, EC4 & $\left.500,000 \mathrm{sq} \mathrm{ft} 46,500 \mathrm{~m}^{2}\right)$ & Planning consent \\
Paddington phases 2/3 & $500,000 \mathrm{sq} \mathrm{ft}\left(46,500 \mathrm{~m}^{2}\right)$ & Planning consent
\end{tabular}


Fall in demand

\section{Tourism campaign}

With so much in the pipeline, how is retail demand in London shaping up? It is apparent from analysis of recent retailer moves on the Metropolis database that many retailers are seeking economies of scale by rationalising into larger premises.

Figures from Focus ${ }^{2}$ suggest that there is demand for 602,500 square feet $\left(56,000 \mathrm{~m}^{2}\right)$ of retail space in the City, spread between 155 retailers, and 570,000 square feet $\left(53,000 \mathrm{~m}^{2}\right)$ is required by retailers in the West End, spread between 170 retailers. Demand by its very nature is very liquid and difficult to quantify, but this snapshot hardly reveals a market in decline.

A recent $\mathrm{DTZ}^{3}$ study found that more than 60 per cent of retailers interviewed expect demand to increase for premises of more than 10,800 square feet $\left(1,000 \mathrm{~m}^{2}\right)$. At the other end of the scale demand for small units has been driven by food, drink and electronics. In particular, mobile telephone sellers and coffee shops have driven demand for units below 2,150 square feet $\left(200 \mathrm{~m}^{2}\right)$ during 2001 and early 2002, although this market has now stabilised. The level of market profiling carried out by retailers is greater than ever. 'Retailers do a lot more research than in the past and the product has to be just right. ${ }^{4}$

Once again, despite buoyant consumer spending retailers remain pessimistic in their own forecasts. More than half the retailers questioned by $\mathrm{DTZ}^{5}$ predict a fall in demand. The reasons? Many retailers face escalating costs as a result of the 2000 rating revaluation and forthcoming rent reviews. Mobile telephone shops alone made up 10 per cent of transactions in 1999-2001, and the collapse in the mobile telecommunications market is expected to prompt closures this year. While West End flagship stores spring up at a great rate, these often lead to the closure of multiple smaller branches. Some retailers even opined, somewhat cynically, 'Retailers often take space because they feel they must expand to please the stock market. ${ }^{6}$

The science of micro location has never been more important in London retailing. In the DTZ survey ${ }^{7}$ retailers stated 'Two years ago, it didn't matter where you went on Oxford Street. Now certain sites will be marked up higher on review than a new shop next door.' It appears that size and location matter more than ever now.

It has long been a truism that West End shop rents rise and fall in direct relation to tourist numbers. In terms of the year ahead there are two sides to this argument. On one hand the fear of flying after September 11th, a weak US economy, the new congestion charge and City job cuts are bad. On the other hand, signs of a recovery in the US economy, resilient consumer spending and a big British tourism campaign in the USA could all dampen the negatives. In fact the London Tourist Board expects tourist numbers in 2002 to top 27 million in London — the second best year ever, confounding gloomy expectations. 


\section{Flagship stores}

$50,000 m^{2}$ of retail under construction

\section{MARKET CONDITIONS BY AREA}

In the West End, retailers continue to consolidate their portfolios, reduce store numbers and focus on a few flagships in prime positions. The closure of C\&A has enabled a new wave of retail lettings in Oxford Street. Next, Gap, Arcadia, Asprey, Tiffany \& Co and H\&M have occupied or are occupying flagship stores south of the main thoroughfare. Demand for Bond Street has proved particularly strong as luxury goods retailers taking large units have given the area a new lease of life. New entrants to the market, such as Mango, Zara and Esprit, are all fitting out flagship stores of more than 10,800 square feet $\left(1,000 \mathrm{~m}^{2}\right)$. Conversely, smaller stores and those in secondary positions are proving difficult to let at both the western and eastern ends of Oxford Street.

While the 'churn' of retail units in the West End has been considerable, there has been only minimal extra floorspace added, as Figure 2 shows.

In Covent Garden, fashion retailers continue to prosper - Zara, Benetton, Uniqlo and Urban Outfitters have requirements in Covent Garden. HMV pre-let 8,070 square feet $\left(750 \mathrm{~m}^{2}\right)$ on King Street, overlooking the north piazza, at an estimated $£ 275$ zone A (zone A refers to the prime floorspace of a shop, usually from the door to about $5 \mathrm{~m}$ back); Derwent Valley's Tower House scheme at 3-11 Southampton Street, WC2 provides 24,750 square feet $\left(2,300 \mathrm{~m}^{2}\right)$ of new retail space - Sainsbury has already pre-let half.

In the City it has been a growing success story as retailers and developers have woken up to the huge potential of the lunchtime spend among Britain's best-rewarded local workforce. About 538,000 square feet $\left(50,000 \mathrm{~m}^{2}\right)$ of retail space is under construction in the City and another 107,600 square feet $\left(10,000 \mathrm{~m}^{2}\right)$ has planning consent. At least 30 multiple stores are looking for space, according to Knight Frank. ${ }^{8}$ The City's $5 \mathrm{~m}$ square feet $\left(464,700 \mathrm{~m}^{2}\right)$ of retail space is concentrated in Liverpool Street, Cheapside and Fenchurch Street. Planners are keen to see this spread, and landlords realise that at rent

Figure 2: West End retail floorspace 1983-2000

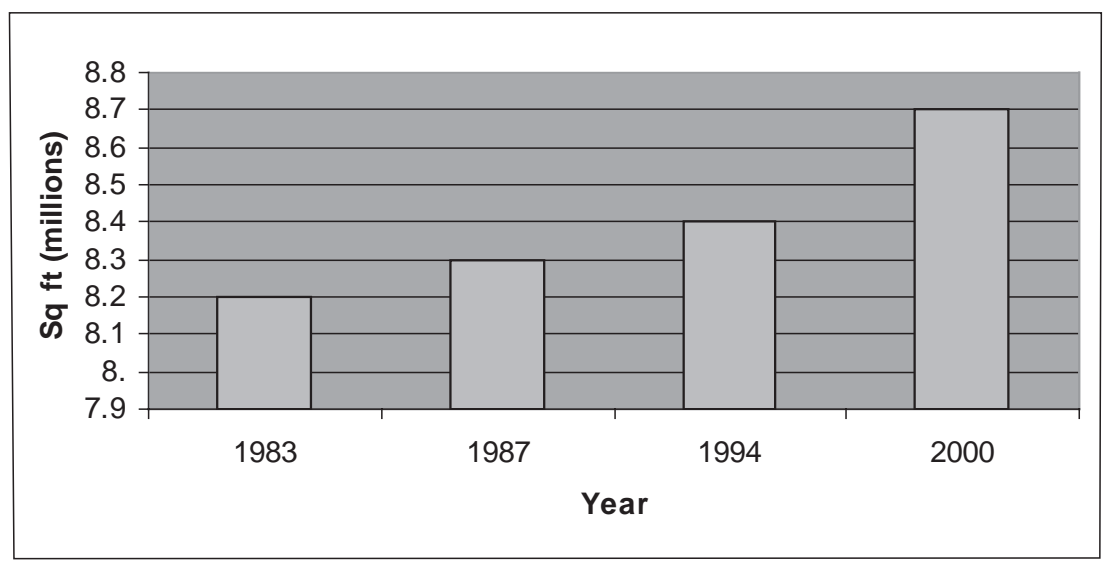

Source: Colliers CRE 


\section{Mixed-use predominates}

\section{Extra $\mathbf{f}_{5}$}

levels of $£ 250$ /square foot zone A, it makes sense to put shopping on the ground floor of offices.

At Canary Wharf in E14, half of the new 90,000 square feet $\left(8,361 \mathrm{~m}^{2}\right)$ Jubilee Place shopping centre has been pre-let to 15 tenants, including Choice, Sean Hanna, Jashan, Itsu and Marks \& Spencer. The new shopping centre will complement the recently opened Waitrose/John Lewis 'Food and Home' store, which is the first of its mixed-format kind in the UK.

\section{RETAIL TRENDS IN LONDON}

Retail trends are changing and evolving very fast as a generation used to responding to 'want' rather than 'need' is influenced by clever marketing and multimedia. Some retailers have been quick to embrace new concepts. For example, the Easy group has followed up its chain of internet cafés with the introduction of in-house McDonald's franchises, while confectionary retailers such as Thorntons have added cafés.

The importance of design is being emphasised in some of the new schemes. Although the highly prestigious refurbishment of the Royal Exchange in EC3 by Bank has attracted a full house of upmarket retailers, pedestrian flows are lower than predicted and retailers are lobbying for the incorporation of a café or coffee bar to bring shoppers in. In Fenchurch Street, EC3, the new Marks \& Spencer building has reputedly had difficulties attracting a tenant because of the image of 'living above the shop'.

In terms of retail planning, 'mixed-use' now predominates with over 90 per cent of large planning applications including more than one type of commercial floorspace. Retail appears in more locations than ever before, below offices, above stations, within public buildings and as part of all leisure schemes. Even the new Home Office headquarters being built in Whitehall will incorporate shop units.

As a result of the rising volume of retail floorspace in London, some areas lose out. Some of the highest vacancy rates are in some of the smaller secondary centres, which have suffered at the expense of the larger dominant centres. Retail areas in the central London fringe - City Road, Bloomsbury, Kings Cross, Pimlico etc - have all suffered from reduced pedestrian flows in recent years. But where a centre dominates its area — such as Oxford Street vacancies are low.

The challenges for central London retail over the next two years are formidable and the effects of the congestion charge are likely to have a negative effect — although probably not major, as few shoppers who can afford central London parking prices will be deterred by an extra $£ 5$. War in the Middle East has kept tourist numbers down. The continuing problems with public transport failures will also keep some away, while suburban centres, such as Croydon with its new Centrale scheme and later Park Place scheme, an expanded Brent Cross in N4 and the new White City scheme, 
will increase their pull on shoppers and retail spending is likely to fall.

The prognosis remains good, however. Central London has proved resilient to outer London shopping centres, the internet, terrorists and tourism downturns, thriving on the diversity of areas such as Oxford Street, Covent Garden and Bond Street to maintain its position as the longest retail strip in the world. Meanwhile, the fast grower is retail in the City of London, with new department stores, a large variety stores and up-market fashion set to change the City for good. Retail spending, fuelled by low interest rates, shows little sign of abating and innovative retailing looks likely to continue to attract the young and the image conscious of a growing metropolis.

Despite the wave of new retail development arriving in central London, the shopping districts are shaping up to continue their diversity and even appeal to new markets. Rents may plateau as new supply feeds through, but as far as London is concerned, it is shaping up to remain the 'biggest fish in a growing pool'.

\section{References}

1. Emap Glenigan/Freeman online database available at www.glenigan.com.

2. See the Focus Retailer Requirements database (www.focusnet.co.uk).

3. Skinner, D. (2002) UK Commercial Property Market Summary, DTZ, March.

4. Ibid.

5. Ibid.

6. Ibid.

7. Ibid.

8. Palmer, C. (2002) Knight Frank Retail Review 2003, Knight Frank Research. 